\title{
Looking for free riding: energy efficiency incentives and Italian homeowners
}

\section{Journal Article}

\section{Author(s):}

Alberini, Anna; Bigano, Andrea; Boeri, Marco

Publication date:

2014-08

Permanent link:

https://doi.org/10.3929/ethz-b-000088216

Rights / license:

In Copyright - Non-Commercial Use Permitted

Originally published in:

Energy Efficiency 7(4), https://doi.org/10.1007/s12053-013-9241-7 


\title{
Looking for free riding: energy efficiency incentives and Italian homeowners
}

\author{
Anna Alberini • Andrea Bigano • Marco Boeri
}

Received: 24 May 2013 / Accepted: 21 November 2013 /Published online: 12 December 2013

(C) Springer Science+Business Media Dordrecht 2013

\begin{abstract}
We examine the effect of energy efficiency incentives on household energy efficiency home improvements. Starting in February 2007, Italian homeowners have been able to avail themselves of tax credits on the purchase and installation costs of certain types of energy efficiency renovations. We examine two such renovations - door/window replacements and heating system replacements - using multi-year crosssection data from the Italian Consumer Expenditure Survey and focusing on a narrow period around the
\end{abstract}

\footnotetext{
A. Alberini $(\triangle)$

Department of Agricultural and Resource Economics, AREC, University of Maryland,

2200 Symons Hall, College Park, MD 20742, USA

e-mail: aalberin@umd.edu
}

A. Alberini

Fondazione Eni Enrico Mattei,

Venice, Italy

A. Alberini

CEPE, ETH,

Zurich, Switzerland

A. Bigano

Fondazione Eni Enrico Mattei,

Milan, Italy

A. Bigano

Euro-Mediterranean Centre for Climate Change,

Venice, Italy

\section{A. Bigano}

Euro-Mediterranean Centre for Climate Change,

Lecce, Italy

M. Boeri

Queen's University,

Belfast, Northern Ireland introduction of the tax credits. Our regressions control for dwelling and household characteristics and economy-wide factors likely to influence the replacement rates. The effects of the policy are different for the two types of renovations. With window replacements, the policy is generally associated with a $30 \%$ or stronger increase in the renovation rates and number of renovations. In the simplest econometric models, the effect is not statistically significant, but the results get stronger when we allow for heterogeneous effects across the country. With heating system replacements, simpler models suggest that the tax credits policy had no effect whatsoever or that free riding was rampant, i.e., people are now accepting subsidies for replacements that they would have done anyway. Further examination suggests a strong degree of heterogeneity in the effects across warmer and colder parts of the country, and effects in the colder areas that are even more pronounced than those for window replacements. These results should, however, be interpreted with caution due to the low rates of renovations, which imply that the effects are estimated relatively imprecisely.

Keywords Energy efficiency policy $\cdot$ Household behavior Italy $\cdot$ Energy consumption survey

JEL Classification Q41 D $12 \cdot \mathrm{H} 3$

\section{Introduction and motivation}

Incentives such as rebates and tax credits are currently offered to homeowners in the US and many other countries to encourage energy efficiency home renovations 
and appliance replacement. Insulation, heating and cooling systems, water heaters, and high-efficiency appliances (such as refrigerators, freezers, clothes washers and dryers, and dishwashers) are typically covered by these programs. A major goal of these policies is to reduce the emissions of greenhouse gases associated with electricity generation and energy use in the home. A possible additional benefit of reducing energy use is that doing so will diminish reliance on fuel imports. Support for these policies is motivated by their large potential, as buildings account for some $30-40 \%$ of all energy use, and alleged low or even negative cost (Levine et al. 2007; Choi Granade et al. 2009).

At least in the US, however, residential energy efficiency incentives have been present since the 1970s (Hassett and Metcalf 1995), usually in the form of income tax credits and other government subsidies, or as Demand Side Management (DSM) programs established and run by the electricity and gas utilities. The latter were usually conducted to aid peak load management and reduce demand so as to avoid investment in infrastructure and the construction of new generation facilities. ${ }^{1}$

Evaluating incentive programs requires answering three key, and related, questions. The first is how responsive households are to the incentive amount: In other words, by how much must the incentive be raised to result in the desired number of energy efficiency adoptions? Second, what is the reduction in energy use (and associated carbon emissions) that can be correctly ascribed to the program? Third, what is the cost (to households, taxpayers, and other parties) per unit of energy or carbon emissions avoided, and how does that compare with that of alternate policies?

Despite the extensive reliance on residential energy efficiency incentives, the evidence about the first question is mixed and inconclusive. Walsh (1989) finds that federal incentives have no effect on energy efficiency renovations (or expenditures). Hassett and Metcalf (1995) use panel data and account for unobserved household heterogeneity using fixed effects, finding that a $10 \%$ increase in the US federal tax credit leads to a $24 \%$ increase in the likelihood of performing energy efficiency home improvements. Boomhower and Davis

\footnotetext{
${ }^{1}$ Earlier assessments of these programs have therefore focused on their effect on the reliability of the electricity supply system (see, for example, Kushler et al. 2003) or in reducing conventional air pollution emissions associated with power generation (e.g., Vine 2003).
}

(2013) deploy a regression discontinuity design to study a large-scale appliance replacement program in Mexico and conclude that the rebate does increase program participation, but not by much: An increase in the rebate offered to consumers from $\$ 110$ to $\$ 170$ (a $54 \%$ increase) raises participation by $21 \%$.

Identifying the energy use reductions that can correctly be attributed to incentive programs - the second key question above - is even more challenging due to the heterogeneity of consumer behaviors and the likelihood that some of them will be counterproductive. Incentive programs are voluntary and as such they may attract persons who are more proficient at reducing energy use or implementing energy efficiency upgrades. The presence of these persons will overstate the costeffectiveness of the program (Joskow and Marron 1992).

An important concern is free riding, which occurs when the economic agents targeted by the policy take the incentives, but would have done the home renovations or appliance replacements anyway. This may happen because (1) the energy efficiency characteristics of the renovation are not separable from other technical or aesthetic features that would have motivated the renovation anyway (new windows that are both pleasant to look at and more heat efficient), (2) the agents were already convinced that the resulting efficiency improvement was worth its cost, or (3) the agents replace existing equipment only when it breaks beyond repair.

An earlier meta-analysis of demand-side management programs conducted by the utilities suggests that the share of free riders ranges between $0 \%$ and $50 \%$ (Joskow and Marron 1992), whereas Malm (1996) estimates that $89 \%$ of the households he examined would have purchased a high-efficiency heating system even in the absence of subsidies. Blumstein (2010) and Vine et al. (2001) discuss the difficulty of recognizing free riders and the use of survey evidence to establish if someone is a free rider. Shorrock (1999) studies the uptake of UK government grants for home insulation and estimates the "natural" rate at which insulation is installed as the intercept in a regression of insulation acquisitions on grant expenditure.

Grösche and Vance (2009) examine renovations using cross-section data from the 2005 German Residential Energy Consumption Survey, and conclude that free riding, which they define as the situation in which a household's willingness to pay for renovations exceeds their cost, occurs in $50 \%$ of the cases. Boomhower and 
Davis (2013) estimate a price elasticity of the demand for appliance replacement, and use it to predict that about three-quarters of the rebate recipients in Mexico are free riders.

In practice, some studies simply assume free ridership away, others assume that the impact of free riders cancels out with other behavioral responses (Haberl et al. 1998), and others yet assume that a specific percentage of the program participants are free riders (e.g., Allaire and Brown 2012). Ignoring free riders overstates the cost-effectiveness of an incentive program - the third key question above-sometimes to a staggering extent (Joskow and Marron 1992). Hartman (1988) establishes that the average conservation truly attributable to an audit program - a popular DSM initiative - is only $39 \%$ of the savings calculated based on a naïve comparison between participants and non-participants. Waldman and Ozog (1996) estimate that the DSM program they analyze accounts for only $71 \%$ of the total conservation, the remaining $29 \%$ being "natural" conservation (i.e., that would have happened regardless).

Based on a nationwide sample of utilities and annual reports on energy sales and DSM expenditures, Loughran and Kulik (2004) estimate that DSM expenditures reduced electricity usage by $0.3-0.4 \%$ at a cost of $\$ 0.14-0.22 / \mathrm{kWh}$, which exceeds the price charged to consumers. This estimate is in sharp contrast with the utilities' own report of $1.8-2.3 \%$ at a cost of $\$ 0.02-$ $0.03 / \mathrm{kWh}^{2}$ Loughran and Kulik conclude that the utilities fail to recognize participant selection into these programs - namely that participants would have done the energy efficiency investment even in the absence of the DSM incentives. ${ }^{3}$

Energy efficiency incentive programs may engender a number of other behavioral effects. Assistance with a specific type of energy efficiency investment, for example, may free up income that can be spent on other, additional energy efficiency investments. Grösche et al. (2013) predict that as incentives increase, households substitute away from simpler, less expensive energy efficiency renovations (such as adding insulation or replacing the heating system) to more

\footnotetext{
$\overline{2}$ The cost-effectiveness figures are somewhat more favorable when attention is restricted to the subset of utilities that report positive DSM expenditures in every year of the study.

${ }^{3}$ Auffhammer et al. (2008) dispute these findings on definitions, metrics, and econometrics grounds.
}

complex and expensive ones (e.g., windows, doors, or other structural changes). The latter are less costeffective in terms of energy savings and carbon emissions reductions.

Gillingham and Palmer (2013) and Blumstein (2010) discuss free drivers, namely persons who do not avail themselves of the incentives offered by a program, but choose to make energy efficiency purchases because their awareness has been raised by the existence of the program. Young (2008) documents another potential threat to energy efficiency incentive programs - namely when individuals accept an incentive and add to the stock of energy-using capital in their homes, rather than replacing an existing, inefficient appliance. She uncovers that a non-negligible share of Canadian households do not dispose of old and inefficient refrigerators once they replace them with new ones. Instead, they keep using them as "beer fridges" (to store cold beverages), for a net increase in electricity consumption. This can be avoided with careful incentive program design, which in turn will increase program complexity and the associated administrative and enforcement costs.

Is free riding widespread in the presence of incentives, and is always as severe as earlier studies have found? If other behavioral responses are present, what is the net effect of an incentive program? In this paper, attention is focused on a tax credit policy for homeowners that has been in place in Italy since February 2007. ${ }^{4}$ Effective from February 19, 2007, a national law allowed homeowners (as well as owners of buildings used for commercial and industrial purposes) to deduct from their income taxes up to $55 \%$ of the expenses sustained to implement certain types of energy efficiency renovations or source of renewable energy in existing homes (commercial buildings). ${ }^{5}$ (Earlier legislation in place since 1998 allowed deductions for renovations - $36 \%$ of expenses - but did not target energy efficiency renovations.)

These include the replacement of the heating system, attic and wall insulation, window and door replacement, the entire building envelope, and solar panels to be used for heating water (photovoltaics are specifically excluded because they are addressed by other laws and

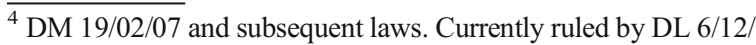
2011.

${ }^{5}$ Caps of $€ 30,000, € 60,000$, and $€ 100,000$ per residential unit apply, depending on the type of renovations.
} 
programs). Applications for the tax credits must be accompanied by a professional engineer's certification of the renovations and estimated energy savings. After 2007, the law was amended, in that changes were made to the number of years over which the tax deductions can be spread. The Italian Renewable Energy Agency (ENEA 2008, 2009, 2010) reports that there were 106,000 filings for the tax deduction for tax year 2007, 248,000 for tax year 2008, and 237,000 for tax year 2009. These documents also calculate the cost-effectiveness of the emissions reductions made possible by the energy savings attributed to these renovations (assuming no free riding). ENEA (2010) reports that in 2009, $49 \%$ of the filings were for window and door replacement, $30 \%$ for heating system replacement, $15 \%$ for thermal solar panels, $4 \%$ for attic or floor insulation ("horizontal" in the language of the law), and $2 \%$ for "vertical" wall insulation.

In this paper, we use household-level data from the Italian Consumer Expenditure Survey to examine the rate at which (potential) energy efficiency home improvements are done and to see whether this rate was affected by the tax credit policy. We take care to avoid attributing to the policy effects that are due to long-term trends or macroeconomic shocks. Specifically, we limit the sample to a narrow "window" (2004-2009) around the introduction of the tax credits policy, test for pretrends, and control for factors likely to affect energy efficiency renovations.

Attention is focused on window/door replacements and heating system replacements. We find that door and window replacements increase when the policy is introduced, especially at locations with harsher climates. The findings are less clear for heating system replacements. The simplest models find that the policy has had no effect whatsoever on heating system replacements, or that free riding must have been pervasive. Further analyses, however, suggest that there is a considerable degree of heterogeneity of the effects across the territory, and that the policy raises the replacement rates and numbers considerably in the colder parts of the country (Northern Italy).

The remainder of the paper is organized as follows. We present data and models in the "Methods" section. "The data" section describes the data. The "Results" section presents the results. "Conclusions" section provides concluding remarks.

\section{Methods}

Data sources

At the time of this writing, no official governmentconducted surveys exist in Italy that are dedicated to residential energy consumption. ${ }^{6}$ Moreover, the individual taxpayer filings authorized by the 2007 tax credit law and described in the ENEA reports are not publicly available. For these reasons, we use information about energy efficiency upgrades in the home using the Italian Consumer Expenditure Survey (Indagine sui Consumi delle Famiglie), which is conducted annually by the Italian Statistics Institute (ISTAT).

We have 13 waves of the Italian Consumer Expenditure Survey. Our dataset is multi-year cross-sections, covers a total of 13 years from 1997 to 2009, before and when the policy was in place, and contains about 23,000 households each year, for a total of 311,456 observations.

The Italian Consumer Expenditure Survey (henceforth abbreviated as I-CEX) gathers information about food and household expenditures incurred in the week prior to the survey, the most recent energy bills, home maintenance expenditures ("manutenzione ordinaria"), and home renovation expenditures ("manutenzione straordinaria") incurred in the last 3 months prior to the interview. Within the latter category, the respondent is specifically asked whether he (1) replaced windows and doors, (2) replaced the heating system, and (3) did other exterior and interior renovations. Clearly, items (1) and (2) are two renovations targeted by the taxdeduction incentive policy, and so we can examine whether they have become more frequent when the incentive is present. The I-CEX questionnaire does not inquire about tax credits for specific energy efficiency upgrades, and so what we do observe is simply whether or not the household did certain types of energy

\footnotetext{
${ }^{6}$ Such surveys are available in other countries. For example, the Energy Information Agency within the US Department of Energy administers the Residential Energy Consumption Survey (see http://www.eia.gov/consumption/residential/). A similar study was conducted in Germany in 2005 (Grösche and Vance 2009) and information about dwellings, renovations, and energy use in the UK is gathered through the English Housing Survey (see https://www.gov.uk/government/uploads/system/uploads/ attachment_data/file/88370/EHS_Headline_Report_2011-2012. pdf) and a variety of household surveys, including the British Household Panel Survey (see Meier and Rehdanz 2010) and the Continuous Household Survey (see Gans et al. 2013).
} 
efficiency renovations, regardless of any tax credits received.

In our regressions (described below), we must control for other factors that influence the propensity to undertake energy efficiency renovations. These include, among others, structural characteristics of the home (e.g., size and vintage of the home) and characteristics of the household, such as income, and the number and ages of the household members (documented in the ICEX). They also include energy prices, climate, and the state of the economy and of the housing market.

Energy prices were gathered from assorted sources, including ISTAT, the Italian Energy Authority, and Eurostat. Weather information comes from the T3 Global Surface Summary of the Day records from the US National Oceanographic and Atmospheric Agency. We obtained daily temperatures from the weather stations in each Region, ${ }^{7}$ and used them to create daily and monthly heating degree days (HDDs) and cooling degree days (CDDs) at the Region level. We further aggregated HDDs and CDDs to annual totals in the 12 months prior to the time of the survey. Although we have weather data at a fine geographical resolution (the monitoring station level), we use regional aggregates because the ICEX dataset only identifies the Region where the household lives.

We use unemployment rates by Region and year dummies to control for the state of the economy, and the sales of homes in the Region, normalized by the population of that Region, to control for the conditions of the housing market. The number of home sales comes from the Agenzia per Il Territorio (the Italian Land Agency), whereas unemployment and population figures are provided by ISTAT.

\section{Theoretical considerations}

Decisions about energy-using capital (or home renovations that improve the thermal integrity of the dwelling) and energy usage are usually represented assuming a two-stage utility maximization process. In the first stage, the household chooses the level of consumption of other goods and the desired level of "energy services" (e.g., thermal comfort). In the second stage, the household chooses the combination of capital stock $K$ and energy

\footnotetext{
${ }^{7}$ In Italy, a Region is a jurisdiction with authority similar to that of a US State, a Canadian Province, or a German Länder. There are a total of 20 Regions in Italy.
}

use $E$ that minimizes expenditure for any given level of energy services. At the optimum, the slope of the isoquant representing the possible combinations of capital and energy for any given technology is equal to the ratio of capital and energy prices.

Figure 1 depicts a possible set of isoquants and isocost lines. The technology represented in isoquant $\mathrm{S} 2$ is more efficient than that in isoquant S1 since the former uses less energy at any given level of capital. At a given initial level of prices, the hypothetical household represented in Fig. 1 selects optimal point A. Subsidies or tax credits expressed as a percentage of the price of capital change the isocost line, which becomes steeper and has a higher $K$-intercept. This results in optimum $B$, which uses more capital and less energy than $A$.

It can be shown that the first-order conditions for the optimum imply that households energy-saving home renovations to the point where the marginal benefit from the investment (the marginal willingness to pay for thermal comfort) is equal to the private marginal cost of the investment. On aggregating the individual households' demand functions, one obtains the market demand for home renovations, which is the solid downward sloping line in Fig. 2. The private optimum number of renovations is $Q_{1}$.

Using energy, however, generates externalities (such as emissions of conventional pollutants and $\mathrm{CO}_{2}$ associated with power generation, excessive load on the grid, dependence on foreign imports of fuel, etc.), and so the social marginal benefit is the dashed line in Fig. 2. The social optimum is $Q^{*}$, which is clearly greater than $Q_{1}$.

Offering a tax credit on the cost of energy efficiency investments lowers the marginal cost of the investment (dashed flat line in Fig. 2), but if households cannot be

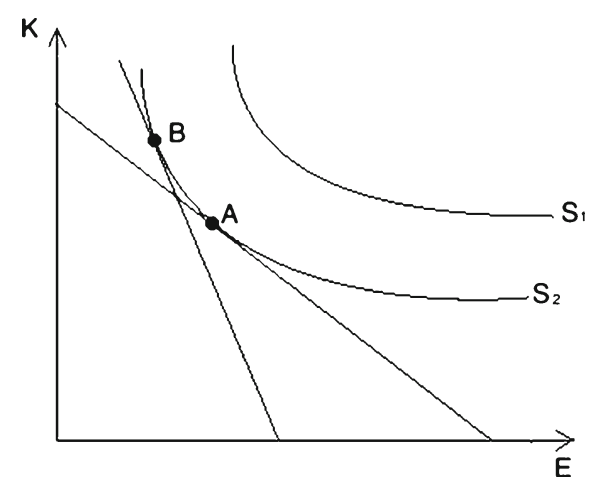

Fig. 1 Optimal choice of capital equipment (or home renovation) and energy use 


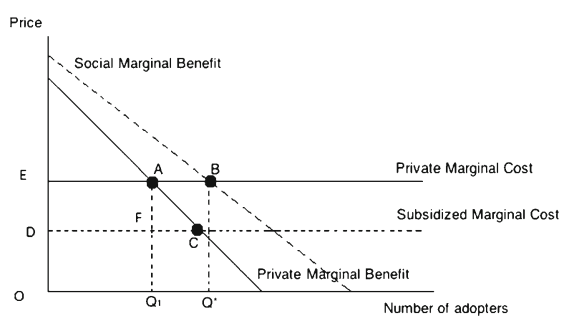

Fig. 2 Social and private marginal benefits and free riding

forced to internalize the externalities associated with energy production and use, the final outcome will be at point $\mathrm{C}$, and those households that would have done the renovation at the initial, unsubsidized cost level-the free riders - will simply pocket the amount of money corresponding to the area of rectangle DFAE.

In this paper, we use household-level data to examine specific energy efficiency upgrade decisions. Our dataset does not document whether a household received incentives to do energy efficiency renovations, and it cannot be used to identify free riders. It does, however, allow us to capture the heterogeneity of the individual households' private benefits.

The theoretical model predicts that a household will replace the heating system, put in new energy efficient windows, or do another energy efficiency upgrade in the home if the net benefits from this renovation (namely, the value of the heating services or thermal integrity, plus other benefits, minus the costs) are positive.

In practice, various factors can affect this basic benefit-cost calculus. The benefits of energy efficiency upgrades should depend on the structural characteristics of the home and household characteristics (e.g., the presence of small children or elderly household members, income, etc.), and are reasonably expected to be larger in harsher climates. One would also expect energy efficiency upgrades to be more attractive than keeping the existing equipment when energy prices are rising or at locations where the energy prices are high.

The costs of a renovation are comprised of the initial outlay to purchase and install the equipment, plus maintenance and operating costs. A government incentive lowers the initial outlay and increases the attractiveness of a home energy efficiency renovation, but only if the cost of applying for the incentive is smaller than the incentive. We would therefore expect incentivesubsidized renovations to account for fewer than $100 \%$ of the total number of renovations.
Our earlier theoretical exposition presumes that individuals are perfectly informed about prices, policies, and equipment technical characteristics, and that they have access to credit to finance their purchases. However, there has been much debate in academic and policy circles about incomplete information, misperceptions, cognitive limitations, restricted access to credit, transaction costs, and on the role played by these factors in the so-called energy efficiency gap (Golove and Eto 1996; Jaffe and Stavins 1994; Allcott and Greenstone 2012). For these reasons, the household's education level, income, and assets may influence decisions, and we control for them in our empirical work.

\section{Econometric approach}

Ideally, to assess the effect of a policy, one would like to have observations before and after the policy from two groups of economic agents - a group that is subject to the policy, and one that is unaffected and thus serves as a control group. Unfortunately, it is not possible for us to implement such a "difference-in-difference" study design due to the lack of a control group in our main source of data. ${ }^{8}$

Given these data limitations, we simply compare the behaviors of (different samples of) homeowners before and after the implementation of the tax credits policy. To avoid attributing to the policy effects that are truly due to other factors, we (1) restrict the sample to a relatively narrow window around the passage of the tax credit law so as to keep conditions relatively constant and free from long-term effects, (2) carefully test for pre-trends, and (3) control for economy-wide shocks and for the conditions of local housing markets. Once the factors in (3) are controlled for, it is assumed that any difference in a household's propensity to do renovations before and during the policy year is solely due to the policy.

\footnotetext{
${ }^{8}$ Renters do not constitute a legitimate control group. Their landlords are still entitled to the tax credits, provided that they meet the other requirements of the law, and at any rate the I-CEX questionnaire does not collect any information on home renovations from those households who rent their homes. Likewise, households living in multi-family housing or the homeowners association are eligible to receive the tax credits. One option might be to select renovations not covered by the tax credits and regard this type of renovations as the "control group." Unfortunately, the Italian Consumer Expenditure Survey gathers data about home renovations using such broad definitions that it is impossible to identify an unambiguous "control" type of renovations.
} 
We check for pre-existing trends by estimating the linear probability model:

$y_{i t}^{(k)}=\alpha+\mathbf{x}_{i t} \beta+\sum_{t} \gamma_{t} D_{t}+\varepsilon_{i t}$

where $(k)$ denotes the type of energy efficiency renovation covered by the policy (e.g., heating system, doors and windows, etc.), $y$ is a dummy that takes on a value of one if the renovation was done in the 3 months prior to the interview, $i$ denotes the household, $t$ the year, and the sample is limited to pre-policy years. Vector $\mathbf{x}$ is comprised of house, household, and economy-wide factors thought to affect the decision to do an energy efficiency home renovation, and the $D$ s are year dummies. We then test the null hypothesis that the coefficients on the year dummies are jointly equal to zero. ${ }^{9}$

After making sure that there are no pre-existing trends, we estimate two econometric models. The first is the linear probability model:

$y_{i t}^{(k)}=\alpha+\mathbf{x}_{i t} \boldsymbol{\beta}+\delta \cdot$ POLICY $_{t}+\varepsilon_{i t}$

where POLICY is a dummy that takes on a value of one in 2007-2009. We test the null hypothesis that $\delta=0$. Failure to reject this null hypothesis would imply that either the policy has no effect (i.e., it has not been sufficient to stimulate energy efficiency renovations) or that there is free riding.

The second is

$y_{i t}^{(k)}=\alpha+\mathbf{x}_{i t} \beta+\sum_{t} \gamma_{t} D_{t}+\delta \cdot \mathrm{POLICY}+\lambda \cdot\left(\mathrm{POLICY}_{t} \times \mathrm{HDD}_{i t}\right)+\varepsilon_{i t}$

which posits that the attractiveness of the incentives depend on local climate. In Eq. (2), HDD denotes the annual degree days.

In this paper, we present regression results for two alternate dummy dependent variables, namely (1) replacing doors and windows and (2) replacing the heating system. These renovations are covered by the tax credit policy, as long as the homeowner is willing to comply with the filing requirements and does file with the tax authority, and indeed replacing doors and windows alone accounted for $49 \%$ of the filings in 2009 , according to ENEA (2010). Heating system

\footnotetext{
${ }^{9}$ An alternate specification that produces similar results simply enters a linear time trend in the right-hand side of Eq. (1) in lieu of the year dummies.
}

replacements accounted for $30 \%$ of the filings in 2009 (ENEA 2010).

We estimate Eqs. (1)-(3) by weighted least squares (using the probability sampling weights provided by the Italian Statistics Institute), and since many variables are measured at the Region level, we cluster the standard errors around the Region (Moulton 1990; Wooldridge 2010, p. 865), which means that our standard errors and $t$ statistics are both heteroskedasticity-robust and robust to the presence of correlation between observations from the same Region. Our sample is restricted to owners of single-family homes and apartments in multi-family dwellings with their own heating system, as long as they live in the homes they own. ${ }^{10}$ We reason that this makes them the bearers of the cost and the beneficiaries of any savings and other consequences of their renovation decisions.

Vector $\mathbf{x}$ includes determinants of energy efficiency investments, such as energy prices, heating and cooling degree days in the Region where the household resides, dwelling characteristics (size, type, and vintage), household characteristics (size, ages and education of the household members, income), and month of the survey. Importantly, $\mathbf{x}$ includes controls for the conditions of the real estate market and for economy-wide factors that might affect a household's propensity to invest in its home.

\section{Additional specifications}

For good measure, we also estimate the probit equivalents of (1)-(3). For example, the probit model corresponding to (3) is

$$
\begin{aligned}
E\left(y_{i t}^{(k)}\right) & =\operatorname{Pr}\left(y_{i t}^{(k)}=1\right) \\
& =\Phi\left(\alpha^{*}+\mathbf{x}_{i t} \boldsymbol{\beta}^{*}+\sum_{t} \gamma_{t} D_{t}^{*}+\lambda^{*} \cdot\left(\mathrm{POLICY}_{t} \times \mathrm{HDD}_{i t}\right)\right)
\end{aligned}
$$

where $\Phi(\bullet)$ is the standard normal cdf. The probit is estimated by weighted maximum likelihood.

When estimating residential fuel demand, researchers often regard the choice of heating fuel as simultaneously determined with the demand for that fuel (e.g., Dubin and McFadden 1984; Mansur et al. 2008). We likewise test for whether a household choice of natural gas as the

\footnotetext{
${ }^{10}$ Depending on the year, $71-76 \%$ of the households in the ICEX own their home, mirroring nationwide homeownership rates.
} 
primary heating fuel is endogenous with the decision to replace windows or the heating system itself. This can be accomplished in a number of ways, all of which are based on two equations. The first equation explains the decision to do the renovation conditional on all regressors and on whether piped gas is used as the heating fuel. The second equation explains whether the household uses piped natural gas for heating as a function of a set of instruments. We experiment with (1) a bivariate probit model as in Evans and Schwab (1995); (2) two simultaneous linear probability models, which are estimated using two stages least squares (Evans and Schwab 1995); and (3) a variant on the Heckman twostep approach.

Formally, approach (1) posits that

$y_{i t}^{(k) *}=\mathbf{x}_{i t} \boldsymbol{\beta}+\operatorname{GASHEAT}_{i t} \cdot \beta_{\mathrm{G}}+\operatorname{POLICY}_{t} \cdot \delta+\varepsilon_{i t}(5)$

$$
\operatorname{GASHEAT}_{i t}^{*}=\mathbf{x}_{i t} \boldsymbol{\theta}+\mathbf{w}_{i t} \boldsymbol{\tau}+\eta_{i t}
$$

where $\mathbf{w}$ is a vector of identifying instruments, $\theta$ and $\tau$ are vector of coefficients, and $\varepsilon$ and $\eta$ are correlated zero-mean error terms. Error terms $\varepsilon$ and $\eta$ are assumed to be jointly normally distributed. By contrast, approach (2) does not make any assumptions about the joint distribution of the error terms and models the binary dependent variables directly (instead of the latent variables $y^{*}$ and GASHEAT*). Finally, approach (3) fits a probit of the decision to use natural gas heat, forms an inverse Mills ratio for it, and enters the latter in the righthand side of a linear probability equation for the decision to do an energy efficient home renovation.

In Eq. (6), our identifying instruments are the length of the gas network in the Region and a proxy for the availability of network gas at the home of the respondent, which we construct as the length of the gas pipelines in the Region of residence interacted with whether the respondent lives in a city.

\section{The data}

The CEX contains a total of over 311,000 observations over 1997-2009, but when attention is restricted to households that own single-family homes (or apartments in multi-family dwellings with their own heating system) and live in them, and we use only 2004-2009 (our preferred "window," see below), the sample size is
86,489. Descriptive statistics of this "restricted" sample are displayed in Tables 1, 2, 3, 4, 5, and 6 .

Figure 3 shows that in the late 1990s home improvements and renovations occurred at a rate of about $10 \%$ a year, and that they have generally been declining since. The rates of replacement for doors/windows and heating systems followed similar trends, and were 2-3\% per year by the last few years of our sample period. The average quarterly renovation rates are $0.8 \%$ for windows and $0.7 \%$ for heating systems. Other studies report similarly low annual energy efficiency renovation rates at other locations (Gans 2012; Grösche and Vance 2009).

If we apply the renovation rates observed in the sample to the population of households the sample is supposed to be representative of (about 15 million households in 2009), we estimate totals of 80,000 119,000 window and door replacements, and 90,000 107,000 heating system replacements, every year over the period from 2004 to 2009 . We predict about 91,000 window/door replacements, and a similar number of heating system replacements, for 2009, the last year in our sample.

Comparison with the filings for the tax credits reported by ENEA is difficult because the population the ICEX represents does not completely overlap with the parties that are allowed to request the tax credits. Our sample is comprised of single-family homeowners and owners of units in multi-family buildings with their own heating systems. All of these households live in a home they own. The tax credit law, however, does not impose the restriction that the applicant should live in the building where the renovations are done, and applies to residential, commercial, and industrial buildings. Both incorporated entities and individual taxpayers are allowed to apply for the tax credits. With these limitations in mind, ENEA reports that in 2009 there were about 115,000 filings for the tax credits for windows and doors, and 68,000 filings for heating system replacements.

Based on the sampling weights reported in the ICEX, the average expenditure on windows and doors renovations on an annual basis is $€ 2,298.53$, and that for heating systems replacements is $€ 2,418.62$. These figures are much smaller than the mean cost per incentivesubsidized renovation reported in the ENEA documents. In 2009, for example, the average cost of window replacements was $€ 9,475$ and that of a heating system replacement was $€ 12,427$. These figures are likely to 
Table 1 Sample and population sizes, and predicted number of window and heating system replacements by year

\begin{tabular}{lllll}
\hline Year & $\begin{array}{l}\text { Obs. in } \\
\text { the } \\
\text { sample }\end{array}$ & $\begin{array}{l}\text { Number of } \\
\text { households in } \\
\text { the population }\end{array}$ & $\begin{array}{l}\text { Number of } \\
\text { window } \\
\text { replacements }\end{array}$ & $\begin{array}{l}\text { Number of } \\
\text { heating system } \\
\text { replacements }\end{array}$ \\
\hline 2004 & 14,482 & $12,927,203$ & 80,461 & 102,257 \\
2005 & 13,967 & $13,104,484$ & 81,722 & 107,269 \\
2006 & 14,177 & $13,646,139$ & 85,740 & 89,853 \\
2007 & 14,942 & $14,093,871$ & 88,271 & 94,144 \\
2008 & 14,685 & $14,834,778$ & 119,097 & 101,973 \\
2009 & 14,236 & $14,683,559$ & 91,103 & 91,596 \\
\hline
\end{tabular}

be inflated by the extensive renovations done on large residential buildings (which account for some $30 \%$ of the total) and on commercial and industrial buildings ( $4 \%$ of the total). Unfortunately, the ENEA reports do not provide detailed information about other moments or order statistics of the distribution of the costs of the renovations.

Table 2 shows that over our preferred study period (2004-2009), about $71 \%$ of the households used network gas for heating, $10 \%$ used gas in bottles or tanks kept outside of the home, and $7 \%$ uses heating oil. Wood is used by about $9 \%$ of the households.

As shown in Table 3, almost $90 \%$ of the households in our sample use a central heating system that is independent of that of neighboring dwelling units, and about $8 \%$ have separate heating devices in different rooms within the home. The remainder (about $3 \%$ ) relies on a central heating system that is shared with other units.

Characteristics of the dwelling, such as the number of rooms and age of the home, are summarized in Table 4. Annual heating degree days and gas prices are displayed in Table 5, whereas Table 6 describes the unemployment rate and the state of the housing market. Table 7 reports information about the demographic and economic circumstances of the household. This includes the time a

Table 2 Heating fuels $(N=86,489)$

\begin{tabular}{lll}
\hline Variable & Freq. & Percent \\
\hline Kerosene, oil, and other liquid fuels & 6,064 & 7.01 \\
Gas (from pipelines) & 61,419 & 71.01 \\
Gas (bottles or outside tanks) & 8,881 & 10.27 \\
Coal, wood, coke, and other solid fuels & 7,534 & 8.71 \\
Other (electricity, solar, etc.) & 2,439 & 2.82 \\
Don't know & 152 & 0.18 \\
\hline
\end{tabular}

Table 3 Type of heating system $(N=86,489)$

\begin{tabular}{lll}
\hline Variable & Freq. & Percent \\
\hline Shared central heating system & 2,318 & 2.68 \\
Independent central heating system & 77,013 & 89.04 \\
Separate heating devices in each room & 7,158 & 8.28 \\
\hline
\end{tabular}

household has been living in the house (duration and duration squared), the household's size, and the number of household members aged 17 or younger (age1) or 65 and older (age4). The I-CEX does not disclose household income, so we proxy income and wealth with the ownership of a car, the number of homes owned, and day-to-day consumption expenditures (on an annual basis).

\section{Results}

Figure 3 suggests that the rates at which households replaced windows or their heating systems declined between 1997 and 2009. All home renovations (inclusive of interior and exterior renovations, plus window and heating equipment replacements) experienced a similar decline.

Our first order of business is, therefore, to identify a sufficiently stable period before the introduction of the tax credit program. We fit Eq. (1) for window replacements and heating system replacements for various preprogram periods, and test the null hypothesis that the coefficients on the year dummies are jointly equal to zero. Both types of renovations appear to be stable when attention is restricted to 2004-2006, so our subsequent regressions use the data from 2004 to 2009, which results in a symmetric "window" around the tax credit law event. ${ }^{11}$

Regression results are reported in Table 8 for window replacements during 2004-2009. We present three specifications. In all of them, the standard errors are clustered at the Region level. Specification (A) corresponds

\footnotetext{
${ }^{11}$ For 2004-2006, the $F$ statistic of the null that the coefficients on the year dummies are equal to zero is $1.65(P$ value 0.2213$)$ for window replacements and $0.83(P$ value 0.4527$)$ for heating system replacements. The $F$ statistics are 2.05 and 3.82, respectively, for 2002-2006, with $P$ values of 0.1320 and 0.0217 . For 2001-2006, they are 1.70 and 2.24 ( $P$ values 0.1894 and 0.1081 ). A longer period (2000-2006) suggests that long-term trends are present ( $F$ statistics 6.07 and 8.13 , respectively, with $P$ values 0.0021 and 0.0003$)$.
} 
Table 4 Characteristics of the dwelling $(N=86,489)$

\begin{tabular}{|c|c|c|c|c|}
\hline Variable & Mean & Std. dev. & Min & Max \\
\hline Home $11-20$ years old & 0.134318 & 0.340995 & 0 & 1 \\
\hline Home $21-30$ years old & 0.178497 & 0.382933 & 0 & 1 \\
\hline Home $31-40$ years old & 0.182717 & 0.386437 & 0 & 1 \\
\hline Home $41-50$ years old & 0.143845 & 0.350934 & 0 & 1 \\
\hline Home more than 50 years old & 0.178508 & 0.382942 & 0 & 1 \\
\hline Home built before 1902 & 0.074183 & 0.26207 & 0 & 1 \\
\hline \# Rooms & 4.666223 & 1.563559 & 1 & 65 \\
\hline Home value & 511.1908 & 268.5978 & 30.14311 & $1,632.355$ \\
\hline Single family home & 0.413787 & 0.492514 & 0 & 1 \\
\hline Urban or suburban area (not rural) & 0.763797 & 0.424751 & 0 & 1 \\
\hline
\end{tabular}

directly to Eq. (2), specification (B) to Eq. (3), and specification $(\mathrm{C})$ keeps the interaction between the policy dummy and HDDs and enters year dummies to make sure that we are not incorrectly attributing to the policy the effect of other macroeconomic shocks.

Starting with specification (A), the model suggests that window replacements are significantly associated with dwelling and household characteristics. The age of the home is a strong predictor of the likelihood that windows are replaced in any given period, as is the size of the home. There is no difference, however, between single-family homes and homes in multi-family dwellings, and rural urban locations. Wealthier and smaller households are more likely to replace their windows in any given quarter. Education and the age composition of the family are not important, but the latter effect is probably confounded by the inclusion of "duration" (the number of years a household has lived in the home), which clearly suggests that the longer the household has lived in the home, the less likely it is to undertake window replacements.

Table 5 Heating degree days $\left({ }^{\circ} \mathrm{F}\right)$ and gas prices (constant 2009 euro/GJ) (source-Eurostat)

\begin{tabular}{lllll}
\hline Variable & Mean & Std. dev. & Min & Max \\
\hline $\begin{array}{l}\text { Annual heating degree } \\
\text { days }\left({ }^{\circ} \mathrm{F}\right)\end{array}$ & $3,386.331$ & $1,238.733$ & 1,140 & $7,473.183$ \\
$\begin{array}{c}\text { Gas prices (in euro } \\
2009 \text { per GJ) }\end{array}$ & 19.14663 & 6.278643 & 0 & 28.26091 \\
\hline
\end{tabular}

We have included the current price of natural gas and the two most recent changes in natural gas prices in the right-hand side of the model, but none of these variables is significantly associated with window replacements. The coefficients on these terms are positive, but statistically insignificant, a result that may be due to measurement error (since we do not know exactly where a person lives, we are forced to attribute to a household the natural gas prices of the major city in the Region). Replacement rates are higher in places with colder climates: The coefficient on HDDs is positive and significant at the conventional levels. In general, despite the very low rate at which window replacements are done, the model identifies a number of significant determinants of window upgrades. ${ }^{12}$

In a regression not reported in this paper, we checked whether there are monthly patterns in window replacement rates. We did not expect to find any since (1) window replacements are not usually done on an emergency basis and (2) windows can be quickly replaced within a day at any time of the year without inconveniencing the occupants of a home, and indeed the $F$ statistic of the null that the coefficients on the month dummies are equal to zero is only 1.83 , for a $P$ value of 0.1275 .

\footnotetext{
${ }^{12}$ The $F$ statistic of the null that the coefficients on all dwelling characteristics are jointly equal to zero is $13.96(P$ value less than $0.0001)$ and that of the null that household characteristics do not matter is 57.23 ( $P$ value less than 0.0001$)$. A similar test also concludes that HDDs and gas prices matter ( $F$ statistic $6.60, P$ value 0.0107$)$, whereas unemployment and the conditions of the housing market are not important ( $F$ statistic $0.45, P$ value 0.6477 ).
} 
Table 6 Economy-wide variables: unemployment rate and home sales rates by Region

\begin{tabular}{lllll}
\hline Variable & Mean & Std. dev. & Min & Max \\
\hline $\begin{array}{l}\text { Unemployment rate } \\
\text { State of the housing } \\
\text { market }\end{array}$ & 0.0130197 & 4.156086 & 2.046852 & 18.67538 \\
& & 0.003317 & 0.006191 & 0.019379 \\
\hline
\end{tabular}

Turning to the policy, in specification (A) the coefficient on the policy dummy is positive and relatively large compared to the rate of occurrence of window replacements. It is, however, estimated imprecisely and statistically insignificant. One possible interpretation of this result is that the policy is ineffective. Another is that the rate at which window replacements are done is simply too low for us to isolate the effects of the tax credits policy. Alternatively, it is possible that the true workings of the policy do not comply with a single, uniform nationwide effect.

We relax this assumption in specification (B), where the interaction between policy and HDD has a positive and significant coefficient. The two policy variables imply that at the mean $\operatorname{HDD}(3,342)$, the effect of the policy is 0.0022 (s.e. 0.0014 ) or about $31.8 \%$ of the average replacement rate. The magnitude of this effect is thus similar to, but slightly larger than, the one from model (A). The $t$ statistic for this effect is, however, only 1.61 .

Increasing the HDDs by one standard deviation (i.e., 1,328 ), which is roughly the difference between Northern Italy and the rest of the country, has a very different effect, depending on whether the tax credit policy is in place or not. In the absence of the policy, window replacement rates increase by 0.0014596 (s.e. $0.0009273)$. When the policy is in place, they increase

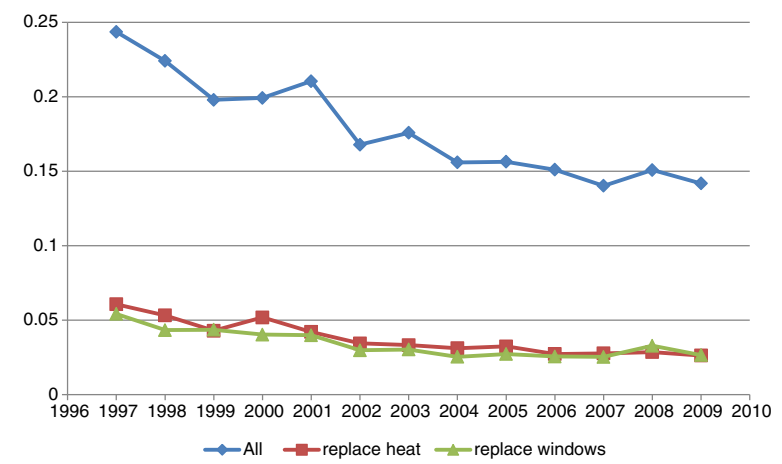

Fig. 3 Annual rates for selected home renovations
Table 7 Characteristics of the household $(N=86,489)$

\begin{tabular}{lllll}
\hline Variable & Mean & Std. dev. & Min & Max \\
\hline Own a car & 0.847807 & 0.35921 & 0 & 1 \\
Own only one home & 0.913931 & 0.280467 & 0 & 1 \\
\# Of homes owned & 0.1071 & 0.376915 & 0 & 8 \\
Day-to-day & $11,882.61$ & $7,746.782$ & 0 & $130,529.9$ \\
$\quad$ consumption & & & & \\
$\quad$ expenditure, annual & & & & \\
$\quad$ total, 2009 euro & & & & \\
Household size & 2.395125 & 1.306664 & 0 & 10 \\
Age1 & 0.352241 & 0.719619 & 0 & 8 \\
Age4 & 0.514193 & 0.714579 & 0 & 5 \\
Duration & 23.29881 & 16.70922 & 0 & 109 \\
Duration squared & 822.0296 & $1,088.86$ & 0 & 11,881 \\
\hline
\end{tabular}

by 0.0031798 (s.e. 0.0009946). This latter effect is strongly statistically significant ( $t$ statistic 3.20$)$ and represents a $37 \%$ increase with respect to the average replacement rate.

Using the results of specification (B), and taking the policy coefficients at face value, we can also predict the window replacement rate with and without the policy, holding the regressors at the sample means for 2006, the last year before the tax credits were passed. The model predicts a quarterly replacement rate of 0.006091 ( $2.4364 \%$ on an annual basis) in the absence of the policy. Holding all regressors at their 2006 levels, the model predicts a replacement rate of 0.008538 (3.4152\% per year) - a $40 \%$ increase. Holding the universe of households the same as in 2006 $(1,364,614$; see Table 1$)$, we predict a total of 83,116 window replacement renovations per quarter in the absence of the policy and 116,512 in the presence of the policy. The associated increase in expenditure is about $€ 63.507$ million (on an annual basis). ${ }^{13}$

In specification $(\mathrm{C})$, we remove the policy dummy (which is always equal to one for 2007 and later years) and include year dummies. The coefficients on the year dummies indicate a decline in window installations over time, but the coefficient on the policy-HDD interaction remains positive and marginally significant.

Turning to the heating system replacement equations (Table 9), dwelling and household characteristics and climate are significantly associated with the likelihood

\footnotetext{
$\overline{13}$ This calculation uses the 2006 mean expenditure per window replacement ( $€ 2,106.59$ on an annual basis, 2009 euro).
} 
Table 8 Window replacement; linear probability model; weighted OLS (all standard errors clustered at the Region level, $N=81,095$ )

\begin{tabular}{|c|c|c|c|c|c|c|}
\hline & \multicolumn{2}{|c|}{ Specification (A) } & \multicolumn{2}{|c|}{ Specification (B) } & \multicolumn{2}{|c|}{ Specification (C) } \\
\hline & Coeff. & $t$ stat. & Coeff. & $t$ stat. & Coeff. & $t$ stat. \\
\hline Gas (from pipelines) & 0.00094 & 0.89 & 0.00089 & 0.85 & 0.00103 & 0.96 \\
\hline Home $11-20$ years old & 0.00304 & 2.32 & 0.00306 & 2.35 & 0.00306 & 2.35 \\
\hline Home $21-30$ years old & 0.00585 & 4.38 & 0.00588 & 4.42 & 0.00589 & 4.39 \\
\hline Home $31-40$ years old & 0.00718 & 4.31 & 0.00719 & 4.32 & 0.00721 & 4.3 \\
\hline Home $41-50$ years old & 0.00826 & 4.89 & 0.00830 & 4.92 & 0.00833 & 4.9 \\
\hline Home more than 50 years old & 0.00832 & 4.12 & 0.00833 & 4.13 & 0.00838 & 4.14 \\
\hline Home built before 1902 & 0.00975 & 6.34 & 0.00974 & 6.33 & 0.00978 & 6.31 \\
\hline \# Rooms & 0.00065 & 1.99 & 0.00066 & 2.01 & 0.00066 & 2 \\
\hline Home value & $1.930 \mathrm{E}-06$ & 1.71 & $1.800 \mathrm{E}-06$ & 1.54 & $1.960 \mathrm{E}-06$ & 1.68 \\
\hline Single family home & 0.00063 & 0.88 & 0.00063 & 0.87 & 0.00059 & 0.81 \\
\hline Urban or suburban area (not rural) & -0.00050 & -0.47 & -0.00047 & -0.45 & -0.00054 & -0.52 \\
\hline Annual heating degree days $\left({ }^{\circ} \mathrm{F}\right)$ & $2.040 \mathrm{E}-06$ & 2.99 & $1.180 \mathrm{E}-06$ & 1.57 & $1.580 \mathrm{E}-06$ & 1.92 \\
\hline Gas prices (in euro 2009 per GJ) & 0.00003 & 0.42 & 0.00004 & 0.54 & -0.00001 & -0.23 \\
\hline Delta gas price & 0.00222 & 1.14 & 0.00206 & 1.04 & 0.00519 & 1.25 \\
\hline Delta1 gas price & 0.00066 & 0.27 & 0.00074 & 0.31 & 0.00539 & 1.55 \\
\hline Own a car & 0.00114 & 1.3 & 0.00112 & 1.29 & 0.00122 & 1.47 \\
\hline Own only one home & -0.00278 & -1.69 & -0.00281 & -1.71 & -0.00298 & -1.97 \\
\hline \# Of homes owned & -0.00151 & -1.4 & -0.00154 & -1.43 & -0.00162 & -1.74 \\
\hline Day-to-day consumption expenditure, annual total, 2009 euro & $1.970 \mathrm{E}-07$ & 2.79 & $1.950 \mathrm{E}-07$ & 2.76 & $2.000 \mathrm{E}-07$ & 2.72 \\
\hline Household size & -0.00071 & -2.6 & -0.00069 & -2.50 & -0.00084 & -2.38 \\
\hline Age1 & 0.00021 & 0.46 & 0.00021 & 0.45 & 0.00026 & 0.55 \\
\hline Age4 & 0.00018 & 0.27 & 0.00018 & 0.26 & 0.00013 & 0.19 \\
\hline Duration & -0.00019 & -2.8 & -0.00019 & -2.79 & -0.00019 & -2.79 \\
\hline Duration squared & $1.400 \mathrm{E}-06$ & 1.39 & $1.390 \mathrm{E}-06$ & 1.39 & $1.360 \mathrm{E}-06$ & 1.37 \\
\hline University degree & 0.00166 & 1.27 & 0.00167 & 1.28 & 0.00164 & 1.27 \\
\hline Unemployment rate & -0.00014 & -0.74 & -0.00017 & -0.87 & -0.00013 & -0.69 \\
\hline Home sale rate & 0.00582 & 0.03 & 0.04519 & 0.23 & -0.07941 & -0.38 \\
\hline Policy & 0.00197 & 1.32 & -0.00243 & -1.29 & & \\
\hline Policy $\times$ annual HDD & & & $1.390 \mathrm{E}-06$ & 1.95 & $1.440 \mathrm{E}-06$ & 1.99 \\
\hline 2005 & & & & & 0.00046 & 0.37 \\
\hline 2006 & & & & & 0.00027 & 0.22 \\
\hline 2007 & & & & & -0.00024 & -0.09 \\
\hline 2008 & & & & & -0.00265 & -1.03 \\
\hline 2009 & & & & & -0.00444 & -1.75 \\
\hline Constant & -0.00754 & -1.25 & -0.00511 & -0.85 & -0.00378 & -0.65 \\
\hline$R$ square & 0.0032 & & 0.0033 & & 0.0034 & \\
\hline$F$ statistic & 5,38 & & 5.31 & & 4.91 & \\
\hline Degrees of freedom of $F$ test & $28,81,066$ & & $29,81,065$ & & $33,81,066$ & \\
\hline$P$ value & $<0.00001$ & & $<0.00001$ & & $<0.00001$ & \\
\hline
\end{tabular}

of replacing the heating system. The tax credit policy, however, enters with a negative and statistically insignificant coefficient, whether by itself or with the companion variable policy $\times$ HDD. 
To illustrate, the average heating system replacement rate is 0.007 per quarter. Specification (B) predicts that at the mean HDD the effect of the policy is only 0.0000421 , a statistically insignificant amount ( $t$ statistic 0.03 ), and that only 574 additional heating system replacements would take place every quarter, assuming that same universe of households as in 2006. These results seem to point to complete policy ineffectiveness and/or extremely high incidence of free riding: Most likely households replace their heating systems when they must (because the system is broken beyond repairs or is at the end of its economic life) and this decision is unaffected by the tax policy.

The model results, however, are also compatible with strongly heterogeneous effects across the territory. In the absence of the tax credit policy, a one standard deviation increase in HDD increases the heating system replacement rate by 0.0031 ( $t$ statistic 3.77 ). If the policy is in place, the corresponding increase would be 0.0045 ( $t$ statistic 2.74). These two effects are large compared to the pre-policy rate of heating system replacement (e.g., 0.00685 in 2006), and imply 42,306 and 61,994 replacements per quarter, respectively, assuming the same universe of households as in 2006. The associated expenditures are $€ 94,288$ million and $€ 138.169$ million (on an annual basis), respectively.

We re-ran all models without weights and obtained results that were qualitatively and quantitatively similar. All results were confirmed when we ran probit regressions in lieu of least squares. We report the results of probit models with specifications comparable to those of Tables 8 and 9 in Appendix 1, Tables 10 and 11. With probit models, we computed the marginal effects of the policy and of heating degree days at the sample means and found that they were virtually undistinguishable from the ones for the linear probability specification. For example, using the results in Table 10 of Appendix 1, specification (A) predicts that the marginal effect of the policy is a 0.0021 increase in the probability of replacing windows. This marginal effect is the same as that from the linear probability model in Table 8 and likewise statistically insignificant.

Specification (B) in Table 10 implies that at the mean HDD the marginal effect of the policy is 0.0019 , which is within $15 \%$ of the marginal effect based on the analogous linear probability model in Table 8 . Finally, increasing the HDD by one standard deviation above the mean increases window replacement rates by 0.0016 in the absence of the policy and by 0.0036 when the policy is in place. The comparable effects from the linear probability model are very close -0.0015 and 0.0032 , respectively.

We note that in all of the specifications reported in Tables 8 and 9, and in Tables 10 and 11 in Appendix 1, having gas heat is regarded as exogenous. This is because when we tested for the endogeneity of the household's choice of natural gas as primary heating fuel, we found no evidence of such endogeneity. This was the case with all three of the approaches we deployed.

We report the results of the bivariate probit model where gas heat is treated as endogenous in Appendix 2. The results show that the exogenous variables deployed to explain the presence of gas heat are generally strongly associated with adopting gas heat: The regression coefficients are statistically significant at the $1 \%$ level or better for at least nine regressors. The coefficient of correlation across the error terms underlying the two equations, however, is only -0.12 and statistically insignificant ( $t$ statistic 0.198). A Wald test and a likelihood ratio test likewise fail to reject the null that the correlation coefficient is zero, which means that there is no evidence that gas heating is endogenous with the decision to replace the windows.

Appendix 3 displays the results of 2SLS estimation of a linear probability model where the dependent variable is the decision to replace the windows and having gas heat is regarded as potentially endogenous. The results show our identifying instruments (gas lines and gas network variables) are strongly associated with the presence of gas heat, as are many other exogenous variables included in the first stage. The coefficient of gas heat is, however, insignificant in the second stage. The coefficient on gas heat is likewise insignificant in the bivariate probit model, and in all of the specifications in Tables 8 and 9, and 10 and 11 in the Appendix. ${ }^{14}$

We also wondered whether the passage of the tax credit program may have encouraged households to wait until after February 19, 2007 to change their windows or heating systems, so that they could avail themselves of the credit. If this was the case, we would expect a "dip" in the replacements rates in 2006, followed by an increase in 2007. We would have expected this effect to be more pronounced for window replacements, on the grounds of the non-emergency nature of these renovations.

\footnotetext{
${ }^{14}$ The results from similar estimation strategies for changing the heating system are similar and available from the authors.
} 
Table 9 Heating replacement; linear probability model; weighted OLS (all standard errors clustered at the Region level, $N=81,095$ )

\begin{tabular}{|c|c|c|c|c|c|c|}
\hline & \multicolumn{2}{|c|}{ Specification (A) } & \multicolumn{2}{|c|}{ Specification (B) } & \multicolumn{2}{|c|}{ Specification $(\mathrm{C})$} \\
\hline & Coeff. & $t$ stat. & Coeff. & $t$ stat. & Coeff. & $t$ stat. \\
\hline Gas (from pipelines) & -0.00095 & -0.65 & -0.00100 & -0.66 & -0.00101 & -0.65 \\
\hline Home $11-20$ years old & 0.00231 & 1.85 & 0.00233 & 1.86 & 0.00233 & 1.86 \\
\hline Home $21-30$ years old & 0.00384 & 2.41 & 0.00386 & 2.41 & 0.00386 & 2.4 \\
\hline Home $31-40$ years old & 0.00388 & 4.49 & 0.00389 & 4.49 & 0.00389 & 4.5 \\
\hline Home $41-50$ years old & 0.00423 & 2.65 & 0.00426 & 2.64 & 0.00427 & 2.66 \\
\hline Home more than 50 years old & 0.00412 & 3.53 & 0.00412 & 3.51 & 0.00412 & 3.54 \\
\hline Home built before 1902 & 0.00355 & 1.94 & 0.00355 & 1.94 & 0.00353 & 1.93 \\
\hline \# Rooms & 0.00095 & 3.19 & 0.00096 & 3.21 & 0.00095 & 3.17 \\
\hline Home value & $-5.600 \mathrm{E}-07$ & -0.42 & $-6.700 \mathrm{E}-07$ & -0.52 & $-6.150 \mathrm{E}-07$ & -0.49 \\
\hline Single family home & 0.00008 & 0.11 & 0.00008 & 0.11 & 0.00008 & 0.1 \\
\hline Urban or suburban area (not rural) & 0.00083 & 2.1 & 0.00086 & 2.08 & 0.00086 & 2.02 \\
\hline Annual heating degree days $\left({ }^{\circ} \mathrm{F}\right)$ & $3.230 \mathrm{E}-06$ & 3.15 & $2.500 \mathrm{E}-06$ & 3.77 & $2.560 \mathrm{E}-06$ & 3.36 \\
\hline Gas prices (in euro 2009 per GJ) & -0.00003 & -0.9 & -0.00002 & -0.72 & -0.00002 & -0.44 \\
\hline Delta gas price & -0.00106 & -1.03 & -0.00120 & -1.14 & 0.00054 & 0.17 \\
\hline Delta1 gas price & -0.00468 & -1.84 & -0.00461 & -1.82 & -0.00261 & -0.61 \\
\hline Own a car & 0.00214 & 1.77 & 0.00212 & 1.77 & 0.00216 & 1.78 \\
\hline Own only one home & -0.00002 & -0.01 & -0.00005 & -0.02 & 0.00042 & 0.13 \\
\hline \# Of homes owned & 0.00205 & 0.69 & 0.00203 & 0.68 & 0.00243 & 0.79 \\
\hline $\begin{array}{l}\text { Day-to-day consumption expenditure, } \\
\text { annual total, } 2009 \text { euro }\end{array}$ & $2.720 \mathrm{E}-07$ & 3.94 & $2.710 \mathrm{E}-07$ & 3.92 & $2.740 \mathrm{E}-07$ & 3.99 \\
\hline Household size & -0.00059 & -1.03 & -0.00058 & -1.00 & -0.00064 & -1.1 \\
\hline Age1 & 0.00135 & 1.56 & 0.00135 & 1.55 & 0.00137 & 1.58 \\
\hline Age4 & 0.00098 & 1.34 & 0.00098 & 1.34 & 0.00095 & 1.3 \\
\hline Duration & -0.00014 & -1.32 & -0.00014 & -1.31 & -0.00014 & -1.31 \\
\hline Duration squared & $1.590 \mathrm{E}-06$ & 0.96 & $1.580 \mathrm{E}-06$ & 0.95 & $1.590 \mathrm{E}-06$ & 0.95 \\
\hline University degree & -0.00013 & -0.15 & -0.00012 & -0.14 & -0.00013 & -0.16 \\
\hline Unemployment rate & 0.00010 & 0.49 & 0.00008 & 0.41 & 0.00007 & 0.34 \\
\hline Home sale rate & 0.03297 & 0.25 & 0.06600 & 0.46 & 0.01046 & 0.06 \\
\hline Policy & -0.00016 & -0.11 & -0.00385 & -1.62 & & \\
\hline Policy $\times$ annual HDD & & & $1.170 \mathrm{E}-06$ & 1.07 & $1.200 \mathrm{E}-06$ & 1.15 \\
\hline 2005 & & & & & 0.00090 & 1.09 \\
\hline 2006 & & & & & -0.00085 & -0.87 \\
\hline 2007 & & & & & -0.00276 & -0.92 \\
\hline 2008 & & & & & -0.00411 & -2.26 \\
\hline 2009 & & & & & -0.00438 & -2.67 \\
\hline Constant & -0.01428 & -1.79 & -0.01224 & -1.89 & -0.01206 & -1.66 \\
\hline$R$ square & 0.0029 & & 0.0029 & & 0.0030 & \\
\hline$F$ statistic & 5.15 & & 5.16 & & 4.82 & \\
\hline Degrees of freedom of $F$ test & $28,81,066$ & & $29,81,065$ & & $33,81,066$ & \\
\hline$P$ value & $<0.00001$ & & $<0.00001$ & & $<0.00001$ & \\
\hline
\end{tabular}

To see if this is the case, we estimated models similar to Eq. (1) but included both pre- and post- policy years (2004 and later years). With both window and heating system replacements, the 
coefficient on the 2006 year dummy was small and not statistically different from those of the previous and following year. We conclude that there is no particular evidence of "strategic" timing of equipment replacement. It must be recognized, however, that it is difficult to make inference from the low rates of equipment replacement observed in the sample.

\section{Conclusions}

This paper has examined the effect of energy efficiency incentives on household decisions to invest in energy efficiency improvements in their home. We used several waves of the Italy Consumer Expenditure Survey. This survey does not ask individuals whether they did receive a tax credit for their energy efficiency renovations, so we have simply examined whether energy efficiency upgrades increased when the policy was in place.

Attention is restricted to households who own single-family homes or apartments in multi-family buildings, and live in their own homes. To avoid incorrectly attributing the effects of long-term trends to the incentive policy that was established in Italy in 2007, we have limited the sample to a relatively narrow window around the introduction of the policy (2004-2009), tested for pre-trends, and controlled for factors thought to influence home renovations in our regressions.

We have examined two types of energy efficiency renovations potentially covered by the policywindow/door replacements and heating system replacements. We reason that the former are unlikely to be dictated by emergency or equipment breakdowns, and they are often done as part of a general update of the dwelling. The latter may be, since heating is needed in the winter, there is no market for used heating systems, and replacements are often done when the existing equipment breaks beyond repairs or at the end of its economic life. Free-riding behavior is possible and likely for either type of renovation.

Our analysis is motivated by simple theoretical considerations that posit that individuals derive utility from the housing and energy services of their homes, and will do energy efficiency upgrades if the net benefits of doing so are greater than the net benefits of keeping the current equipment. Our econometric model is a linear probability model. Our simplest specification assumes that the effect of the policy is uniform over time and for all climates; we subsequently relax these assumptions.

The estimation results suggest that the tax incentive policy was more effective in encouraging window replacements in harsher climates, and that, all else the same, the policy would raise window replacements by $37-40 \%$ in sufficiently cold climates. Our simplest models suggest that the policy has no "bite" with heating system replacements, or that free riding is almost complete with this type of equipment. On further examination, however, the regression results indicate that the effects of the policy are heterogeneous across the territory and are in fact sizeable in the colder parts of the country.

Caution is needed when interpreting these results. The replacement rates are always very small, which in turn means that the effects of the policy are estimated imprecisely. We do not know whether a household actually applied for and received a tax credit for its renovations, or was even aware of the tax credits policy. Given the typical expenditure associated with the renovations documented in the I-CEX, we suspect that for most of the households here examined the administrative burden was sufficiently heavy to discourage filing, even if the household was aware of the tax credit policy. In closing, we wish to emphasize that, in order to study energy efficiency renovations and upgrades, and to make inference about the likely effects of policies aimed at influencing energy use, energy efficiency improvements in homes, and the adoption of alternate sources of energy in Italy, it will be important to design and administer surveys that are specifically designed for these purposes.

Acknowledgments The authors are very grateful to Francesco Bosello, Cristina Cattaneo, Roberta Distante, Massimo Filippini, and Elena Verdolini for helpful discussions. We are also grateful to the attendees of the 12th IEAEE congress in Venice, the 5th EMEE workshop in Berlin, and the CEPE seminar series at ETH Zurich, where this paper was presented, for their comments and suggestions. This research was funded by the European Union's Seventh Framework Programme (FP7/2007-2013) under grant agreement No. 265325 (PURGE-Public health impacts in URban environments of Greenhouse gas Emissions reduction strategies). 


\section{Appendices}

Appendix 1. Probit models

Table 10 Window replacement: probit model $(N=81,095)$; weighted maximum likelihood estimation

\begin{tabular}{|c|c|c|c|c|c|c|}
\hline & \multicolumn{2}{|c|}{ Specification (A) } & \multicolumn{2}{|c|}{ Specification (B) } & \multicolumn{2}{|c|}{ Specification (C) } \\
\hline & Coeff. & $t$ stat. & Coeff. & $t$ stat. & Coeff. & $t$ stat. \\
\hline Gas (from pipelines) & 0.08184 & 1.12 & 0.07896 & 1.09 & 0.09112 & 1.24 \\
\hline Home $11-20$ years old & 0.19560 & 1.99 & 0.19546 & 1.98 & 0.19623 & 1.99 \\
\hline Home $21-30$ years old & 0.34550 & 4.98 & 0.34641 & 5.01 & 0.34846 & 4.99 \\
\hline Home $31-40$ years old & 0.40992 & 6.05 & 0.41141 & 6.07 & 0.41475 & 6.02 \\
\hline Home $41-50$ years old & 0.46142 & 5.91 & 0.46266 & 5.89 & 0.46677 & 5.92 \\
\hline Home more than 50 years old & 0.44644 & 4.45 & 0.44688 & 4.45 & 0.45121 & 4.49 \\
\hline Home built before 1902 & 0.50772 & 7.46 & 0.50893 & 7.44 & 0.51231 & 7.53 \\
\hline \# Rooms & 0.02827 & 2.46 & 0.02864 & 2.49 & 0.02829 & 2.49 \\
\hline Home value & 0.00011 & 1.65 & 0.00010 & 1.58 & 0.00012 & 1.82 \\
\hline Single family home & 0.02974 & 0.73 & 0.03003 & 0.73 & 0.02655 & 0.63 \\
\hline Urban or suburban area (not rural) & -0.03618 & -0.62 & -0.03610 & -0.62 & -0.04161 & -0.73 \\
\hline Annual heating degree days $\left({ }^{\circ} \mathrm{F}\right)$ & 0.00012 & 3.02 & 0.00007 & 1.37 & 0.00009 & 1.77 \\
\hline Gas prices (in euro 2009 per GJ) & 0.00452 & 0.59 & 0.00520 & 0.66 & -0.00054 & -0.14 \\
\hline Delta gas price & 0.09185 & 0.82 & 0.07820 & 0.69 & 0.33184 & 1.50 \\
\hline Delta1 gas price & 0.00371 & 0.02 & 0.00756 & 0.05 & 0.34774 & 1.79 \\
\hline Own a car & 0.10265 & 2.07 & 0.10146 & 2.04 & 0.10510 & 2.23 \\
\hline Own only one home & -0.14787 & -1.78 & -0.15089 & -1.80 & -0.15481 & -2.11 \\
\hline \# Of homes owned & -0.08358 & -1.48 & -0.08492 & -1.50 & -0.08606 & -1.85 \\
\hline Day-to-day consumption expenditure, annual total, 2009 euro & $8.95 \mathrm{E}-06$ & 3.78 & $8.89 \mathrm{E}-06$ & 3.71 & $9.15 \mathrm{E}-06$ & 3.70 \\
\hline Household size & -0.03765 & -2.53 & -0.03747 & -2.50 & -0.04458 & -2.40 \\
\hline Age1 & 0.01412 & 0.53 & 0.01480 & 0.56 & 0.01752 & 0.63 \\
\hline Age4 & 0.00550 & 0.15 & 0.00519 & 0.15 & 0.00232 & 0.06 \\
\hline Duration & -0.00834 & -2.69 & -0.00828 & -2.67 & -0.00813 & -2.61 \\
\hline Duration squared & 0.00006 & 1.14 & 0.00006 & 1.12 & 0.00006 & 1.09 \\
\hline University degree & 0.08075 & 1.46 & 0.08150 & 1.47 & 0.08032 & 1.48 \\
\hline Unemployment rate & -0.01890 & -1.66 & -0.02099 & -1.80 & -0.01894 & -1.62 \\
\hline Home sale rate & -3.72967 & -0.37 & -1.87595 & -0.19 & -10.88154 & -1.10 \\
\hline Policy & 0.12364 & 1.17 & -0.19126 & -1.01 & & \\
\hline Policy $\times$ annual HDD & & & 0.00009 & 1.79 & 0.00010 & 1.96 \\
\hline 2005 & & & & & 0.02192 & 0.31 \\
\hline 2006 & & & & & 0.00016 & 0.00 \\
\hline 2007 & & & & & -0.08794 & -0.43 \\
\hline 2008 & & & & & -0.27825 & -1.35 \\
\hline 2009 & & & & & -0.38281 & -1.84 \\
\hline Constant & -3.34723 & -10.39 & -3.16215 & -9.53 & -3.00281 & -11.08 \\
\hline Pseudo $R$ squared & 0.0426 & & 0.0433 & & 0.0466 & \\
\hline Wald statistic & 192.28 & & 202.10 & & 215.96 & \\
\hline Degrees of freedom of Wald test & 28 & & 29 & & 33 & \\
\hline$P$ value & $<0.00001$ & & $<0.00001$ & & $<0.00001$ & \\
\hline
\end{tabular}


Table 11 Heating system replacement: probit model $(N=81,095)$; weighted maximum likelihood estimation

\begin{tabular}{|c|c|c|c|c|c|c|}
\hline & \multicolumn{2}{|c|}{ Specification (A) } & \multicolumn{2}{|c|}{ Specification (B) } & \multicolumn{2}{|c|}{ Specification (C) } \\
\hline & Coeff. & $t$ stat. & Coeff. & $t$ stat. & Coeff. & $t$ stat. \\
\hline Gas (from pipelines) & -0.04079 & -0.53 & -0.04281 & -0.55 & -0.04148 & -0.51 \\
\hline Home $11-20$ years old & 0.13427 & 1.99 & 0.13508 & 2.00 & 0.13428 & 1.99 \\
\hline Home $21-30$ years old & 0.20670 & 2.42 & 0.20820 & 2.42 & 0.20783 & 2.39 \\
\hline Home $31-40$ years old & 0.20617 & 3.88 & 0.20726 & 3.90 & 0.20668 & 3.91 \\
\hline Home $41-50$ years old & 0.21769 & 2.48 & 0.21886 & 2.47 & 0.21925 & 2.49 \\
\hline Home more than 50 years old & 0.20374 & 3.84 & 0.20356 & 3.79 & 0.20286 & 3.80 \\
\hline Home built before 1902 & 0.17245 & 1.87 & 0.17118 & 1.85 & 0.16988 & 1.83 \\
\hline \# Rooms & 0.03748 & 3.76 & 0.03796 & 3.83 & 0.03746 & 3.77 \\
\hline Home value & -0.00002 & -0.33 & -0.00003 & -0.46 & -0.00002 & -0.38 \\
\hline Single family home & 0.00245 & 0.06 & 0.00323 & 0.08 & 0.00249 & 0.06 \\
\hline Urban or suburban area (not rural) & 0.03991 & 1.76 & 0.02245 & 0.08 & 0.03923 & 1.67 \\
\hline Annual heating degree days $\left({ }^{\circ} \mathrm{F}\right)$ & 0.00018 & 3.26 & 0.00012 & 3.24 & 0.00013 & 3.00 \\
\hline Gas prices (in euro 2009 per GJ) & -0.00381 & -1.74 & 0.00196 & 0.13 & -0.00306 & -1.11 \\
\hline Delta gas price & -0.05318 & -0.81 & -0.07026 & -1.04 & 0.06790 & 0.35 \\
\hline Delta1 gas price & -0.26918 & -2.01 & 0.13693 & 0.05 & -0.10337 & -0.45 \\
\hline Own a car & 0.19028 & 2.89 & 0.18812 & 2.87 & 0.19009 & 2.89 \\
\hline Own only one home & -0.01807 & -0.20 & -0.01857 & -0.20 & -0.00015 & 0.00 \\
\hline \# Of homes owned & 0.07154 & 0.84 & 0.07086 & 0.82 & 0.08688 & 0.99 \\
\hline $\begin{array}{l}\text { Day-to-day consumption expenditure, } \\
\text { annual total, } 2009 \text { euro }\end{array}$ & 0.00001 & 6.39 & 0.00001 & 6.33 & 0.00001 & 6.31 \\
\hline Household size & -0.02211 & -0.84 & -0.02217 & -0.83 & -0.02564 & -0.95 \\
\hline Age1 & 0.05958 & 1.66 & 0.06050 & 1.68 & 0.06197 & 1.74 \\
\hline Age4 & 0.04615 & 1.44 & 0.04604 & 1.44 & 0.04443 & 1.38 \\
\hline Duration & -0.00704 & -1.23 & -0.00697 & -1.22 & -0.00685 & -1.21 \\
\hline Duration squared & 0.00008 & 0.97 & 0.00008 & 0.96 & 0.00008 & 0.95 \\
\hline University degree & 0.00127 & 0.03 & 0.00234 & 0.06 & 0.00223 & 0.05 \\
\hline Unemployment rate & 0.00037 & 0.03 & -0.00232 & -0.23 & -0.00287 & -0.29 \\
\hline Home sale rate & -2.03470 & -0.35 & 6.26274 & 0.99 & -4.26467 & -0.52 \\
\hline Policy & -0.05064 & -0.70 & -0.39274 & -2.70 & & \\
\hline Policy $\times$ annual HDD & & & 0.00010 & 1.83 & 0.00010 & 2.09 \\
\hline 2005 & & & & & 0.03668 & 0.80 \\
\hline 2006 & & & & & -0.05436 & -1.06 \\
\hline 2007 & & & & & -0.32041 & -1.94 \\
\hline 2008 & & & & & -0.43387 & -3.62 \\
\hline 2009 & & & & & -0.45948 & -3.50 \\
\hline Constant & -3.50434 & -9.79 & -3.31829 & -11.96 & -3.28574 & -10.47 \\
\hline Pseudo $R$ squared & 0.0342 & & 0.0353 & & 0.0359 & \\
\hline Wald statistic & 195.01 & & 188.78 & & 194.21 & \\
\hline Degrees of freedom of Wald test & 28 & & 29 & & 33 & \\
\hline$P$ value & $<0.00001$ & & $<0.00001$ & & $<0.00001$ & \\
\hline
\end{tabular}


Appendix 2

Table 12 Bivariate probit model, $N=81,095$; weighted maximum likelihood estimation (all standard errors clustered at the Region level)

\begin{tabular}{|c|c|c|c|c|c|}
\hline Dep. var.: replace windows & Coeff. & $t$ stat. & Dep. var.: gas heat & Coeff. & $t$ stat. \\
\hline Gas heat (from pipelines) & 0.2789241 & 0.29 & Day-to-day consumption & $4.13 \mathrm{E}-07$ & 0.25 \\
\hline House $11-20$ years old & 0.1979619 & 2.08 & No gas network 2006 & -2.45526 & -7.07 \\
\hline House $21-30$ years old & 0.3518979 & 5.49 & Gas network km hp 2006 & 0.000353 & 0.25 \\
\hline House $31-40$ years old & 0.4131897 & 6.74 & Gas network km mp 2006 & $-2.3 \mathrm{E}-05$ & -0.36 \\
\hline House $41-50$ years old & 0.4630001 & 6.07 & Gas network km lp 2006 & $8.20 \mathrm{E}-06$ & 0.34 \\
\hline Home $50+$ years old & 0.4548458 & 5.46 & Urban or suburban area (not rural) & 0.817974 & 11.52 \\
\hline Home built before 1902 & 0.5256832 & 6.13 & Own a car & 0.083058 & 2.12 \\
\hline Number of rooms & 0.0315911 & 1.31 & Owns only one home & -0.15935 & -1.98 \\
\hline Home value & 0.0000621 & 0.23 & Number of homes owned & -0.05359 & -1.46 \\
\hline SF home & 0.0303026 & 0.76 & House $11-20$ years old & -0.07778 & -2.25 \\
\hline Urban or suburban area (not rural) & -0.0818747 & -0.29 & House $21-30$ years old & -0.19601 & -4.11 \\
\hline Annual HDD $\left({ }^{\circ} \mathrm{F}\right)$ & 0.000109 & 1.15 & House $31-40$ years old & -0.15287 & -3.04 \\
\hline Gas price $(2009 €$ per GJ) & 0.0007985 & 0.04 & House $41-50$ years old & -0.12003 & -2.1 \\
\hline Delta gas price & 0.1167229 & 0.6 & Home $50+$ years old & -0.24874 & -5.38 \\
\hline Delta 1 gas price & 0.0159187 & 0.12 & Home built before 1902 & -0.42088 & -7.36 \\
\hline Owns a car & 0.0970132 & 1.44 & Annual HDD $\left({ }^{\circ} \mathrm{F}\right)$ & 0.000236 & 2.18 \\
\hline Owns only one home & -0.1347115 & -2 & Gas price $(2009 €$ per GJ) & -0.014 & -0.93 \\
\hline Number of homes owned & -0.0762928 & -1.69 & Delta gas price & 0.095798 & 0.62 \\
\hline Day-to-day consumption & $8.87 \mathrm{E}-06$ & 3.3 & Delta1 gas price & 0.350451 & 2.12 \\
\hline Household size & -0.035109 & -1.77 & Home value & 0.000875 & 8.21 \\
\hline Age1 & 0.0128644 & 0.42 & Number of rooms & -0.06546 & -4.9 \\
\hline Age4 & 0.004913 & 0.14 & Household size & -0.02647 & -1.92 \\
\hline Duration & -0.0082657 & -2.45 & Age1 & 0.015307 & 1.39 \\
\hline Duration squared & 0.0000629 & 1.45 & Age4 & 0.01556 & 1.09 \\
\hline University degree & 0.0808303 & 1.46 & Duration & -0.00223 & -1.22 \\
\hline Unemployment rate & -0.0178556 & -1.3 & Duration squared & $-4.2 \mathrm{E}-05$ & -2.02 \\
\hline Home sale rate & -5.684117 & -0.52 & Unemployment rate & -0.00815 & -0.3 \\
\hline Policy & 0.0779002 & 0.34 & Home sale rate & 61.40947 & 2.47 \\
\hline \multirow[t]{2}{*}{ Constant } & -3.301822 & -6.66 & Policy & 0.175324 & 1.27 \\
\hline & & & Constant & -0.88003 & -1.15 \\
\hline Rho (correlation coeff.) & -0.1158767 & 0.198 & & & \\
\hline $\log L$ & $-38,869,138.00$ & & & & \\
\hline \multicolumn{6}{|l|}{ Wald test of rho $=0: \chi^{2}(1)=0.03924$ Prob $>\chi^{2}=0.8430$} \\
\hline Wald $\chi^{2}$ (57 dof) & $10,804.22$ & & $P=0.0000$ & & \\
\hline
\end{tabular}


Appendix 3

Table 13 Weighted 2SLS instrumental variable estimation (linear probability equations), $N=81,095$

\begin{tabular}{|c|c|c|c|c|c|}
\hline \multicolumn{3}{|l|}{ First stage } & \multicolumn{3}{|l|}{ Second stage } \\
\hline Dep. var.: gas heat & Coeff. & $t$ stat. & Dep. var.: replace windows & Coeff. & $t$ stat. \\
\hline & & & Gas heat (from pipelines) & -0.00062 & -0.54 \\
\hline House $11-20$ years old & -0.0112 & -2 & House $11-20$ years old & 0.003025 & 2.31 \\
\hline House $21-30$ years old & -0.0355 & -6.09 & House $21-30$ years old & 0.005794 & 4.4 \\
\hline House $31-40$ years old & -0.01725 & -2.9 & House $31-40$ years old & 0.007152 & 4.32 \\
\hline House $41-50$ years old & -0.00291 & -0.48 & House $41-50$ years old & 0.008247 & 4.89 \\
\hline House $50+$ years old & -0.02058 & -3.43 & House $50+$ years old & 0.008259 & 4.11 \\
\hline House built before 1902 & -0.05273 & -7.18 & House built before 1902 & 0.009618 & 6.18 \\
\hline Number of rooms & -0.01165 & -10.7 & Number of rooms & 0.000637 & 1.93 \\
\hline Home value & 0.00014 & 22.14 & Home value & $2.23 \mathrm{E}-06$ & 1.94 \\
\hline SF home & -0.11357 & -33.75 & SF home & 0.000441 & 0.62 \\
\hline Urban or suburban area (not rural) & 0.200309 & 48.55 & Urban or suburban area (not rural) & -0.00017 & -0.15 \\
\hline Annual HDD $\left({ }^{\circ} \mathrm{F}\right)$ & $4.49 \mathrm{E}-05$ & 16.62 & Annual HDD $\left({ }^{\circ} \mathrm{F}\right)$ & $2.17 \mathrm{E}-06$ & 2.95 \\
\hline Gas price $(2009 €$ per GJ) & -0.00464 & -4.8 & Gas price (2009€ per GJ) & $6.63 \mathrm{E}-05$ & 0.94 \\
\hline Delta gas price & 0.0422 & 3.83 & Delta gas price & 0.001979 & 0.99 \\
\hline Deltal gas price & 0.097877 & 8.2 & Delta1 gas price & 0.000512 & 0.21 \\
\hline Owns a car & 0.001197 & 0.27 & Owns a car & 0.001186 & 1.36 \\
\hline Owns only one home & -0.01576 & -1.18 & Owns only one home & -0.00288 & -1.77 \\
\hline Number of homes owned & -0.00516 & -0.51 & Number of homes owned & -0.00157 & -1.46 \\
\hline Day-to-day consumption & $-3.11 \mathrm{E}-07$ & -1.52 & Day-to-day consumption & $1.97 \mathrm{E}-07$ & 2.79 \\
\hline Household size & -0.00315 & -1.88 & Household size & -0.00073 & -2.7 \\
\hline Age1 & -0.00155 & -0.55 & Age1 & 0.000219 & 0.47 \\
\hline Age4 & 0.006982 & 2.98 & Age4 & 0.000193 & 0.29 \\
\hline Duration & -0.00013 & -0.43 & Duration & -0.00019 & -2.79 \\
\hline Duration squared & $-8.41 \mathrm{E}-06$ & -1.86 & Duration squared & $1.36 \mathrm{E}-06$ & 1.37 \\
\hline University degree & 0.039528 & 9.42 & University degree & 0.001736 & 1.33 \\
\hline Unemployment rate & 0.000582 & 0.79 & Unemployment rate & -0.00014 & -0.76 \\
\hline Home sale rate & 15.25015 & 16 & Home sale rate & 0.019961 & 0.1 \\
\hline Policy & 0.031324 & 3.56 & Policy & 0.002389 & 1.5 \\
\hline No gas network 2006 & -0.44687 & -21.38 & Constant & -0.00803 & -1.32 \\
\hline Gas network km hp 2006 & 0.000119 & 4.15 & & & \\
\hline Gas network km mp 2006 & $-5.76 \mathrm{E}-06$ & -5.23 & & & \\
\hline Gas network km lp2006 & $1.94 \mathrm{E}-06$ & 4.93 & & & \\
\hline Autonomous & -0.12358 & -13.27 & & & \\
\hline Separate & -0.70775 & -70.58 & & & \\
\hline Constant & 0.564594 & 16.27 & & & \\
\hline
\end{tabular}




\section{References}

Allaire, M., \& Brown, S., (2012). "US energy subsidies: effects on energy markets and carbon emission," prepared for the Pew Charitable Trusts, http://www.pewtrusts.org/uploadedFiles/ wwwpewtrustsorg/Reports/Fiscal_and_Budget_Policy/ EnergySubsidiesFINAL.pdf.

Allcott, H., \& Greenstone, M. (2012). Is there an energy efficiency gap? Journal of Economic Perspectives, 26(1), 3-28.

Auffhammer, M., Blumstein, C., \& Fowlie, M. (2008). Demandside management and energy efficiency revisited. The Energy Journal, 29(3), 91-104.

Blumstein, C. (2010). Program evaluation and incentives for administrators of energy efficiency programs: can evaluation solve the principal/agent problem? Energy Policy, 38, 62326239.

Boomhower, J., \& Davis, L. W. (2013). Free riders and the high cost of energy-efficiency subsidies. Berkeley: University of California. March.

Choi Granade, H. et al. (2009). Unlocking Energy Efficiency in the U.S. Economy, McKinsey Global Energy and Materials, available at http://www.mckinsey.com/en/Client_Service/ Electric_Power_and_Natural_Gas/Latest_thinking/ Unlocking_energy_efficiency_in_the_US_economy.aspx (last accessed 17 August 2011).

Dubin, J. A., \& McFadden, D. (1984). An econometric analysis of residential electric appliance holdings and consumption. Econometrica, 52(2), 345-362.

ENEA (2008). Le detrazioni fiscali del $55 \%$ per la riqualificazione energetica del patrimonio edilizio esistente nel 2007, Rome, Italy. http://efficienzaenergetica.acs.enea.it/doc/rapporto_ 2007.pdf.

ENEA (2009). Le detrazioni fiscali del $55 \%$ per la riqualificazione energetica del patrimonio edilizio esistente nel 2008, Rome, Italy. http://efficienzaenergetica.acs.enea.it/doc/rapporto_ 2008.pdf.

ENEA (2010). Le detrazioni fiscali del $55 \%$ per la riqualificazione energetica del patrimonio edilizio esistente nel 2009, Rome, Italy. http://efficienzaenergetica.acs.enea.it/doc/rapporto 2009.pdf.

Evans, W. N., \& Schwab, R. (1995). Finishing high school and starting college: do catholic schools make a difference? Quarterly Journal of Economics, CX(4), 941-974.

Gans, W. L. (2012). The role of prices and information in residential energy consumption and investment behavior. $\mathrm{PhD}$ dissertation, University of Maryland, College Park, April.

Gans, W., Alberini, A., \& Longo, A. (2013). Smart meter devices and the effect of feedback on residential electricity consumption: evidence from a natural experiment in Northern Ireland. Energy Economics, 36, 729-743.

Gillingham, K., \& Palmer, K. (2013). "Bridging the energy efficiency gap," Resources for the Future discussion paper 1302 , Washington, DC, January.

Golove, W. H., \& Eto, J. H. (1996). Market barriers to energy efficiency: a critical reappraisal of the rationale for public policies to promote energy efficiency. Berkeley: Lawrence Berkeley Laboratory, UC Berkeley.

Grösche, P., \& Vance, C. (2009). Willingness-to-pay for energy conservation and free-ridership on subsidization: evidence from Germany. The Energy Journal, 30, 141-160.
Grösche, P., Schmidt, C. M., \& Vance, C. (2013). Identifying freeriding in home-renovation programs using revealed preference data. Journal of Economics and Statistics, 233, 600618.

Haberl, H., Adensam, H., \& Geissler, S. (1998). Optimal climate protection strategies for space heating: the case of Austria. Energy Policy, 26(15), 1125-1135.

Hartman, R. S. (1988). Self-selection bias in the evaluation of voluntary energy conservation programs. The Review of Economics and Statistics, 70(3), 448-458.

Hassett, K. A., \& Metcalf, G. E. (1995). Energy tax credits and residential conservation investment: evidence from panel data. Journal of Public Economics, 57, 201-217.

Jaffe, A. B., \& Stavins, R. N. (1994). The energy efficiency gap. What does it mean? Energy Policy, 22(10), 804-810.

Joskow, P. L., \& Marron, D. B. (1992). What does a megawatt really cost? Evidence from utility conservation programs. The Energy Journal, 13, 41-73.

Kushler, M., Vine, E., \& York, D. (2003). Using energy efficiency to help address electric systems reliability: an initial examination of 2001 experience. Energy, 28, 303-317.

Levine, M., Ürge-Vorsatz, D., Blok, K., Geng, L., Harvey, D., Lang, S., Levermore, G., Mehlwana, A. M., Mirasgedis, S., Novikova, A., Rilling, J., \& Yoshino, H. (2007). "Residential and commercial buildings," (pp 53-58) in Climate Change 2007.

Loughran, D. S., \& Kulik, J. (2004). Demand-side management and energy efficiency in the United States. The Energy Journal, 25(1), 19-43.

Malm, E. (1996). An action-based estimate of the free-rider fraction in electric utility DSM programs. The Energy Journal, $25,19-44$.

Mansur, E., Mendelsohn, R., \& Morrison, W. (2008). Climate change adaptation: a study of fuel choice and consumption in the US. Journal of Environmental Economics and Management, 55(2), 175-193.

Meier, H., \& Rehdanz, K. (2010). Determinants of residential space heating expenditures in Great Britain. Energy Economics, 32, 949-959.

Moulton, B. R. (1990). An illustration of a pitfall in estimating the effect of aggregate variable on micro units. The Review of Economics and Statistics, 72, 334-338.

Shorrock, L. D. (1999). An analysis of the effect of government grants on the uptake of home insulation measures. Energy Policy, 27, 155-171.

Vine, E. (2003). Opportunities for promoting energy efficiency in buildings as an air quality compliance approach. Energy, 28, 319-341.

Vine, E., du Pont, P., \& Waide, P. (2001). Evaluating the impact of appliance efficiency labeling programs and standards: process, impact, and market transformation evaluations. Energy, 26, 1041-1039.

Waldman, D. M., \& Ozog, M. T. (1996). Natural and incentiveinduced conservation in voluntary energy management programs. Southern Economic Journal, 62(4), 1054-1071.

Walsh, M. J. (1989). Energy tax credits and housing improvements. Energy Economics, 11(4), 275-284.

Wooldridge, J. M. (2010). Econometric analysis of cross section and panel data (2nd ed.). Cambridge: MIT Press.

Young, D. (2008). Who pays for the 'beer fridge'? Evidence from Canada. Energy Policy, 36, 353-560. 